\title{
Influence of DNA-Markers Kap 1.3, Cast, Lep 387 on the Productivity of Sheep of the Caucasian and Edilbaevskaya Breeds
}

\author{
Vladimir Lushnikov and Andrey Strilchuk* \\ Saratov State Agrarian University named after N.I. Vavilov, Saratov, 410012, 1 Teatralnaya \\ Ploshchad, Russian Federation
}

\begin{abstract}
Recently, all over the world, breeding work has been carried out with the active use of the methods of modern genetics. The article presents the results of a study of the relationship between the DNA markers of calpastatin (CAST) and leptin (LEP 387) with the meat productivity of Edilbaev sheep, as well as KAP 1.3 with the wool productivity of Caucasian sheep. It was revealed that these DNA markers have a sufficient level of polymorphism in the studied breeds, as well as presence of a relationship between the genotypes of the studied DNA markers with the productivity of the studied breeds.
\end{abstract}

\section{Introduction}

One of the approaches to increasing the efficiency of breeding work is use of DNA markers that allow selection of parental forms at the gene level, that is, selection by genotype directly at the DNA level $[11,12]$.

The calpastatin gene (CAST) is one of the promising candidate genes (markers) associated with the rate of body weight gain, the quality of sheep meat and other economically useful traits, the level of manifestation of which is directly related to the economic success of sheep breeding [1,7]. A number of studies have shown the relationship of calpastatin with lethal yield, fat percentage, birth weight and average daily gain $[6,9]$.

One of the best studied DNA markers associated with meat production is the leptin gene (LEP 387), also known as the "obesity gene". Its product is the hormone leptin, which controls body saturation, regulating weight and metabolism. The relationship between the leptin gene, the concentration of the hormone in the blood and the meat qualities of cattle was confirmed [3]. The relationship between the leptin gene and the fat tail size and the average daily weight gain in sheep has been shown [2, 5].

The KAP 1.3 gene, previously known as $\mathrm{B} 2 \mathrm{C}$, was first noted for its polymorphism by Rogers GR. [10], identifying alleles X and Y. Identification of the polymorphism of this gene and its variability with fiber diameter will be a priority in sheep breeding in selection and breeding work $[4,8]$.

\section{Methods}

* Corresponding author: andreiasp@yandex.ru 
To study the relationship of the polymorphism of the DNA markers CAST, LEP 387 with the meat productivity of sheep, blood samples were taken from Edilbaev sheep rams bred in OOO PR Selkhozservice in the Saratov region, from 33 and 32 heads, respectively. The study of the relationship of the KAP 1.3 gene polymorphism with wool productivity of sheep was carried out on blood samples of the Caucasian bright breed, grown in the ZAO PR Krasny Partizan, Saratov region, selected from 60 heads.

The genotyping of the animals under study was carried out using a polymerase chain reaction followed by analysis of the restriction fragment length polymorphism in the DNA technology laboratory of the All-Russian Research Institute of Breeding.

The slaughter and the study of the meat productivity of the rams were carried out according to the method of VIZH (1978). The pre-slaughter and slaughter weights were studied according to GOST - $7598-81$

Wool was collected by pinching a sample weighing 150-200 g from the side of the body. The yield of pure fiber was determined by the method of VNIIOK (1991) in the laboratory of the Department of TPPPZH on the basis of the Saratov State Agrarian University named after N.I. Vavilov.

Determination of the washed wool yield was carried out according to the GOST 301902000 method.

Statistical processing of the obtained research results was carried out using the Microsoft Office complex using the Microsoft Excel program.

\section{Results}

Using PCR-RFLP analysis of the DNA marker calpastatin (CAST), the genotypes MM with a frequency of 0.88 and $\mathrm{MN}$ with a frequency of 0.12 were found in the studied population of Edilbaev sheep. No homozygous NN genotype was found.

Table 1. Meat productivity of Edilbaevskaya rams in the context of calpastatin gene polymorphism, $\mathrm{kg}$.

\begin{tabular}{|c|c|c|c|c|c|}
\hline Genotype & $\mathrm{n}$ & $\begin{array}{c}\text { Pre-slaughter } \\
\text { weight }\end{array}$ & $\begin{array}{c}\text { Slaughter } \\
\text { weight }\end{array}$ & $\begin{array}{c}\text { Slaughter } \\
\text { exit }\end{array}$ & Fat tail mass \\
\hline MM & 28 & $35.4 \pm 0.93$ & $14.9 \pm 0.47$ & 42.2 & $1.73 \pm 0.13$ \\
\hline MN & 5 & $36.2 \pm 1.9$ & $15.8 \pm 0.96$ & 43.6 & $2 \pm 0.27$ \\
\hline
\end{tabular}

From the above data (Table 1), it can be concluded that there was no practical difference between the indicators of meat productivity of the studied rams with different genotypes. In terms of pre-slaughter weight, rams with the MN genotype $(36.2 \mathrm{~kg})$ surpass their peers with the MM genotype $(35.4 \mathrm{~kg}$ ) by $2.26 \%$. In terms of slaughter weight, the difference is also small - the slaughter weight of rams with the MN genotype $(15.8 \mathrm{~kg})$ is higher than that of rams with the MM genotype $(14.9 \mathrm{~kg})$ by $6.04 \%$. A similar trend is observed in terms of slaughter yield, this indicator in rams with the MN genotype (43.6\%) prevails over indicators of rams with the MM genotype $(42.2 \%)$ by $1.4 \%$. The most distinct difference is observed between the data obtained on the weight of the fat tail, this indicator in rams with the MM genotype ( $2 \mathrm{~kg}$ ) is higher than in rams with the MN genotype (1.73 $\mathrm{kg}$ ) by $15.61 \%$.

The study of the leptin gene polymorphism (LEP 387) in the Edilbaev sheep breed showed that the homozygous GG genotype with a frequency of occurrence of 0.86 was predominant among the genotypes, GT heterozygotes accounted for $14 \%$ of the total investigated population, and the TT genotype was absent (Table 2).

Table 2. Meat productivity of Edilbaevskaya rams in the context of leptin gene polymorphism (LEP $387), \mathrm{kg}$. 


\begin{tabular}{|c|c|c|c|c|c|}
\hline Genotype & $\mathrm{n}$ & $\begin{array}{c}\text { Pre-slaughter } \\
\text { weight }\end{array}$ & $\begin{array}{c}\text { Slaughter } \\
\text { weight }\end{array}$ & $\begin{array}{c}\text { Slaughter } \\
\text { exit }\end{array}$ & $\begin{array}{c}\text { Fat tail } \\
\text { mass }\end{array}$ \\
\hline GG & 27 & $35.7 \pm 0.9$ & $15.1 \pm 0.44$ & 42.2 & $1.78 \pm 0.13$ \\
\hline GT & 5 & $32.7 \pm 1.9$ & $13.8 \pm 0.99$ & 43.6 & $1.48 \pm 0.24$ \\
\hline
\end{tabular}

Analyzing the data from the table above, it shall be noted the superiority of rams with the GG genotype over rams with the GT genotype in terms of pre-slaughter weight by $9.17 \%$. The same situation is observed according to the slaughter weight, in rams with the GG genotype $(15.1 \mathrm{~kg})$ this indicator exceeds the rams with the GT genotype $(13.8 \mathrm{~kg})$ by $9.42 \%$. The same pattern can be seen in the fat tail mass indicators, where rams with the GG genotype $(1.78 \mathrm{~kg}$ ) exceed their peers with the GT genotype $(1.48 \mathrm{~kg})$ by $20.27 \%$.

The results of the study of the KAP 1.3 gene (Table 3) on the group of the bright Caucasian breed show that the distribution of genotypes is characterized by a high frequency of occurrence of homozygous animals with genotype XX (0.53), in second place in frequency of occurrence are heterozygous individuals with genotype XY (0.38) and in third place are homozygotes with the YY genotype (0.08).

Table 3. Indicators of wool productivity in bright animals of various genotypes for the KAP 1.3 gene.

\begin{tabular}{|l|c|c|c|}
\hline Genotypes & $\mathrm{XX}$ & $\mathrm{XY}$ & $\mathrm{YY}$ \\
\hline Quantity, heads & 32 & 23 & 5 \\
\hline Frequency of occurrence & 0.53 & 0.38 & 0.08 \\
\hline Degree of fineness, $\mu \mathrm{m}$ & $20.32 \pm 0.17$ & $20.05 \pm 0.19$ & $20.14 \pm 0.07$ \\
\hline Length, mm & $63.28 \pm 2.19$ & $55.87 \pm 2.00$ & $48.00 \pm 3.74$ \\
\hline Crimp, deg/mm & $91.03 \pm 2.51$ & $95.24 \pm 2.71$ & $105.4 \pm 5.49$ \\
\hline Sheared pure wool, $\mathrm{kg}$ & $2.36 \pm 0.07$ & $1.91 \pm 0.07$ & $2.24 \pm 0.12$ \\
\hline Washed wool yield, \% & $56.97 \pm 1.06$ & $53.10 \pm 1.54$ & $59.40 \pm 4.53$ \\
\hline
\end{tabular}

\section{Discussion}

The indicators of wool productivity of bright colors presented in the table, taking into account the genotypes for the KAP 1.3 gene, showed that the gimbers with the XX genotype have the highest wool fineness (20.32 microns) compared to the gimbers with the $\mathrm{XY}$ genotype by $1.33 \%$ and the YY genotype by $0.88 \%$. Gimbers with homozygous genotype XX had the longest hair $(63.28 \mathrm{~mm})$ and had an advantage of $12.13 \%(\mathrm{P}>0.95)$ over gimbers with genotype XY and by $24.15 \%(\mathrm{P}>0.99)$ over gimbers with genotype YY.

Gimbers with genotype XX had not only the greatest fineness, length, but also the smallest crimp of the wool fiber $(91.03 \mathrm{deg} / \mathrm{mm})$. The most crimped wool were those of the gimbers with the YY genotype, which was 105.4 degrees per millimeter. This indicator has an advantage over gimbers with genotype $\mathrm{XX}$ by $13.63 \%(\mathrm{P}>0.95)$ and over gimbers with genotype XY - by $9.64 \%$.

The gimbers with the XX genotype had the highest value of the pure wool shear index $(2.36 \mathrm{~kg})$ in comparison with the peers of other genotypes. The lowest rate of shearing of pure wool was found in bright animals with genotype XY, the average weight of which reached $1.91 \mathrm{~kg}$, which is $19.07 \%(\mathrm{P}>0.999)$ less than in bright animals with genotype $\mathrm{XX}$ and by $14.73 \%(\mathrm{P}>0.95)$ - than in YY genotypes.

In terms of the yield of washed wool, the gimbers with the XX genotype were in second place. The gimbers with the YY genotype (59.40\%) had some advantage. The difference in indicators was insignificant and amounted to $4.09 \%$ over the gimbers with the $\mathrm{XX}$ genotype and $10.61 \%$ over the gimbers with the XY genotype. 


\section{Conclusion}

The revealed polymorphism, as well as the distribution of indicators of meat and wool productivity, depending on the genotypes of the studied DNA markers, allows further research in this direction to identify desirable and undesirable genotypes, which in turn will allow more careful selection and selection and breeding work with the studied breeds of sheep.

\section{References}

1. A.V. Dejkin, M.I. Selionova, A.YU. Krivoruchko, D.V. Kovalenko, V.I. Truhachev, Vavilovskij zhurnal genetiki i selekcii, 20, 5 (2016)

2. K. Javed, M. E. Babar, T. Hussain, A. Ali, Pakistan J. Zool, 50, 3 (2018)

3. D. Boucher, M. F. Palin, F. Castonguay, C. Gariépy, and F. Pothier, Canadian Journal of Animal Science, 86 (2006)

4. R. Bailey, Interscience (New York, 1950)

5. Hajihosseinlo, Adv. Biomed. Res., 4, 172 (2015)

6. A.H.M., I. Mirghani, M. F. Shehata, Journal of American Science, 11, 3 (2015)

7. D. Hristova, I. Dimitrova, N. Stancheva, M. Bozhilova-Sakova, J. BioSci. Biotechnol, 4, 1 (2015)

8. R. Kumar, M A.S.Meena, R. Kumari, B. Jyotsana, L.L. Prince, S. Kumar, Indian Journal of Small Ruminants, 22, 1 (2016)

9. O. Yilmaz, T. Sezenler, N. Ata, Y. Yaman, Article in Turkish Journal of Veterinary and Animal Sciences, 38 (2014)

10. G.R. Rogers, J.G.H. Hickford, R. Bickerstaffe, Animal Genetics (1993)

11. R. Wakchaure, S. Ganguly, P.K. Praveen, A. Kumar, S. Sharma, T. Mahajan, Journal of Drug Metabolism \& Toxicology, 6, 5 (2015)

12. K. Yadav, S. S. Tomar, A. K. Jha, J. Singh., 5, 4 (2017) 